\title{
LOCAL BRANDING STRATEGIES IN SOUTHEAST ASIAN ISLAMIC CULTURES
}

\author{
Shakila Yacob1,4 , ${ }^{*}$ Rosilawati Zainol ${ }^{2,4} \&{ }^{*}$ Hanafi Hussin ${ }^{3,5}$ \\ *Corresponding Author \\ ${ }^{1}$ Department of History, Faculty of Arts and Social Sciences, \\ ${ }^{4}$ Center for Civilisational Dialogue, \\ ${ }^{2}$ Centre for Sustainable Urban Planning and Real Estate (SUPRE), Department \\ of Urban and Regional Planning, Faculty of Built Environment, \\ ${ }^{3}$ Department of Southeast Asian Studies, Faculty of Arts and Social Sciences, \\ Institute of Ocean and Earth Sciences \\ University of Malaya \\ (shakila@um.edu.my, rosilawatizai@um.edu.my \& hanafih@um.edu.my) \\ DOI: https://doi.org/10.22452/jati.vol23no1.6
}

\begin{abstract}
In the beauty industry, local companies lose and the foreign companies win in nearly all places around the world. However, it is believed that in Islamic and traditional cultures, local companies have a competitive edge over foreign multinational companies, an edge that impacts consumer choices. What contributes to this edge combines the concepts of Warisan (traditional and cultural) and halal (an Islamic concept of purity and cleanliness) that are applied by local companies in Malaysia, Indonesia and Thailand to compete against multinational companies and win battles for profits. In the beauty industry, the literature lacks an explanation of why consumers choose certain beauty product brands and the reasons for their choices in Malaysia, Indonesia and Thailand. To understand the impacts on consumers' choices between local and international brands and to evaluate the effectiveness of branding strategies in the beauty industry, a survey was conducted in Indonesia (Jakarta), Malaysia (Kuala Lumpur) and Thailand (Bangkok). In total, 361 questionnaire surveys were conducted with female respondents at various locations in the three countries. The study found that despite the fact that local companies leveraged their competitive advantages, beauty product users in Indonesia, Malaysia and Thailand preferred product qualities such as suitability, quality and indigenous ingredients to local or foreign brands. International brands had a significant impact on consumers in each of the three countries. However, global brands did not use a halal logo demonstrating that consumers preferred foreign over local brands despite the
\end{abstract}


high level of awareness for halal products and ingredients (including indigenous herbs), that international brands did not offer. Indigenous branding strategies that emphasized halalness and indigenous knowledge of herbs were less impactful on brand choice. The quality, suitability, and ingredients took precedence over the halal factor.

Keywords: Southeast Asian Islamic cultures, halal, indigenous knowledge, indigenous ingredients, tayyibah

\section{Introduction}

In response to globalization, various international companies shifted their approach from multi-domestic marketing to global marketing. Consequently, phenomenal changes emerged in branding strategies and more efforts were placed on creating international brands and giving up local brands (Schuiling \& Kapferer, 2004). This shift revealed that international companies also used local brands but gradually moved to single international brands and branding strategies. However, in regional and local markets especially in Southeast Asia, the dominance of international companies has gradually weakened due to changes in the competitive business landscape. Local companies have gained an important place in the beauty industry market because of low operational costs, good networking and a clear understanding of local peoples' tastes and needs (Nielsen Growth \& Emerging Markets, 2016). Understanding local tastes and needs is a primary tactic that local companies have adopted to attract consumers (Schuiling \& Kapferer, 2004).

In 2016, Nielsen Growth \& Emerging Markets conducted a survey to assess the growth and impacts of local, regional and international companies in Southeast Asia. In this survey, different sectors were included as well as various items produced by the beauty industry such as shampoo, hand soaps and body soaps. The survey indicates movement towards the gradual success of local brands over international brands and also mentions local peoples' needs and tastes as factors that opened up space for local companies to gain profits (Nielsen Growth \& Emerging Markets, 2016). However, the survey entirely disregarded religious concepts in countries like Malaysia, Indonesia and Brunei. This disregard excluded a large number of Muslim populations whose peoples' lives and religious and cultural factors greatly determine livelihoods. The survey explicitly missed accounting for religious concepts such as halal (pure and clean), Warisan (traditional heritage) and indigenous knowledge that many believe (Majid, Sabir, \& Ashraf, 2015; Shaari, Khalique, 
\& Aleefah, 2014) dominate Southeast Asian markets.

According to the United Nations Educational, Scientific and Cultural Organization (UNESCO), indigenous knowledge "refers to the understandings, skills, and philosophies developed by societies with long histories of interaction with their natural surroundings. For rural and indigenous peoples, local knowledge informs decision-making about fundamental aspects of day-to-day life. This knowledge is integral to a cultural complex that also encompasses language, systems of classification, resource use practices, social interactions, ritual and spirituality" (UNESCO, n.d.). The notion of beauty among indigenous Southeast Asians has placed a strong emphasis on the cultural heritage that simultaneously shapes the branding of indigenous knowledge of herbs. By exploiting local indigenous knowledge of herbs, knowledge that almost solely lies with women, most of the beauty companies in Southeast Asia produce products for internal and external uses by promoting notions of beauty from within as well as without. In the cultural construction of any notion of beauty, there are many alternatives that those who are responsible for marketing beauty products have to be sensitive to. Underpinning the marketability of beauty products is the Islamic concept of halal, being clean and pure. Alserhan (2010, p. 44) states that the concept of halalness "encompasses not only foods and drinks, but all other matters of daily life; it includes everything a Muslim does: trade, finance, entertainment, work, education, consumption and so on".

Islam as a way of life encompasses a pure and ethical lifestyle or tayyibah (pure and clean). The term tayyibah is used for the life of the Prophet Muhammad (Peace be upon Him) as Hayat-e-Tayyibah, meaning the pure or noble life of the Prophet. Tayyibah is also used in the phrase Madina-e-Tayyibah which means the City of Purity because the city became pure after the migration of the Prophet to the city. A person becomes Muslim by saying shahada, meaning that he or she is purifying himself or herself from the impurities by accepting one Allah and Muhammad as Allah's messenger. Therefore, the Islamic way of life includes purity, cleanliness, and care for the human body as well as the social, economic and natural (flora and fauna) environment in which a person lives and one's relationship with the Creator (Yunus, Wan Chik, \& Mohamad, 2010; Hai, 2001). Thus, the branding of halal beauty products is associated with eco-ethical practices, cruelty-free, environmentally friendly, natural and organic products that are permissible and free of harmful ingredients. Finally, there must be an element of fair trade and non-exploitation of people. This principle is the ethical business model championed by Islam (Sulaiman, Hisam, \& Sanyal, 2013; Butt, Rose, Wilkins, \& 
Ul Haq, 2017).

The Islamic concept of halal (or tayyibah) underpins the marketability of beauty products among Southeast Asian communities, especially in Indonesia and Malaysia (Yunus et al., 2010). Halal or Islamic religious brands are created in light of Islamic principles that producers abide by in the food industry, banking, finance, clothing, hospitality, pharmaceutical and cosmetics, and covers every aspect of life (Alserhan, 2010; Wadood, 2008). The Islamic concept of halal offers different choices for customers as well as for businessmen in Southeast Asia's beauty market. The legitimacy or credibility of indigenous knowledge is also underpinned by Islamic principles (Shakila \& Zainol, 2014). The halal market is divided into three interlinked categories: food, lifestyle and services. Shakila and Zainol reiterate that the slow development of the lifestyle category compared to food is due to the lack of urgency. But as Muslims learned that halal extends beyond food, Islamic-compliant and lifestyle-related products began to be developed to meet the needs of this market and to take advantage of the opportunities provided. The halal cosmetics industry is said to be the next emerging sector after halal food and Islamic finance (Alserhan, 2010).

Muslims worldwide spent $\$ 83$ billion on pharmaceuticals and $\$ 57.4$ billion on cosmetics in 2016 alone (State of the Global Islamic Economic Report $2017 / 18$, 2017). In 2015, the market value of halal cosmetic products around the world was approximately 20 billion US dollars and is supposed to reach 54 billion US dollars by 2022 (Statistica, n.d.).

Johansson and Ronkainen (2005), Schuiling and Kapferer (2004), and Özsomer (2012) show customers' preferences for local brands because of local products' cultural roots and uniqueness (Johansson \& Ronkainen, 2005; Schuiling \& Kapferer, 2004). Cayla and Eckhardt (2007) argue that Asian brands must focus on modernity rather than common cultural heritage. This paper aims to extend the emerging discussion in the very nascent literature collection (Holt, Quelch, \& Taylor, 2004; Thompson \& Arsel, 2004) on brands as socio-cultural entities. This multinational study of the beauty and fashion industry in Southeast Asia explores the differences and similarities between consumers and their choices and behaviors toward beauty products. It is interesting to note that Indonesia is one of the largest Muslim countries in the world at $88 \%$ of the country's population, compared to Malaysia at $60.4 \%$ and Thailand at $14 \%$. Thus an investigation was conducted to evaluate if culturalreligious factors do play a role in customers' brand choices. It is also important to note that in 2017 , the estimated GDP per capita for Indonesians was $\$ 12,400$ which is lower than Malaysians at $\$ 28,900$ and Thais at $\$ 17,800$ (CIA, 2018). 
Indigenous and religious knowledge are not only part of national heritage and pride in countries such as Indonesia and Malaysia, but also constitute the power of resistance to dominant stereotypes from the West (Wane, 2013). In these countries, local beauty products enjoyed a competitive edge over Western products because local products have a halal tag that complies with specific social, cultural and religious criteria that competing foreign products often did not have (Majid et al., 2015; Shaari et al., 2014).

In this scenario, local beauty products enjoyed a competitive edge because they were guaranteed to be halal, fulfilling specific criteria that foreign competition products may not adhere to. For example, products that are halal do not contain animal or human by-products. Additionally, relevant government agencies strictly regulate the permitted level of alcohol according to Islamic law. Halal certification adds value to products with the ability to gain access to a broader global Muslim market and is a source of competitive advantage for halal beauty products against Western and Japanese products. Without the halal certification, these markets are otherwise inaccessible (Emirates Business 24/7, 2009). On the other hand, however, halal certification efforts are challenging to attain in part due to the lack of global halal standards that firms developing products for Muslim markets can follow (Alserhan, 2010). All government-backed agencies and large Muslim groups and institutions are trustworthy sources for halal certification. Saudi, Emirati, Sudanese and Malaysian approvals are highly regarded by Muslims globally (Alserhan, 2010).

In Malaysia, Indonesia and Thailand there are only certain government agencies that are permitted to grant official halal certification to products mostly food and beverages. Other industry sectors such as personal care and cosmetics must undergo a rigorous process before they are endorsed. The Department of Islamic Development Malaysia (JAKIM), Majelis Ulama Indonesia (MUI) and the Central Islamic Council of Thailand (CICOT) are the main bodies that provide halal certification in Malaysia, Indonesia and Thailand respectively. Nonetheless, in Malaysia, another government body, the Halal Development Corporation (HDC), actively plays a role in marketing and promoting halal products globally. This religious aspect offers a different choice from the dominant global brands in the Southeast Asian beauty market. Moreover, by using religious beliefs, indigenous knowledge-based beauty products can reach out to the global Muslim market. Thus, the legitimacy or credibility of indigenous knowledge is underpinned by Islamic principles.

In this paper, we investigate the evolution of home-grown product brands which may differ from similar Western beauty product brands despite 
some researchers' assertions that branding techniques and theories can be applied universally (Czinkota \& Ronkainen, 2003). In fact, Cayla and Arnould (2008) state that there is a "persistent belief among Western branding professionals that Chinese brands and their Asian cousins are not authentic brands" and seem to suggest that "Asian brands lack the emotional connection that Western brands have established with consumers" (pp. 93-94).

Building on Cayla and Arnould's (2008) recommendation for the future research to explore how brand cultures emerge out of different geographies, this paper aims to investigate the brand evolution of local beauty products that originated in the Malay archipelago and their competitiveness with foreign brands in the local market (Cayla \& Arnould, 2008). The significance of cultural-religious factors in the brand building of these beauty products is explored in the analysis of the survey data in this paper. The literature on the relationship between halal beauty cosmetics and personal care products or brands and consumers' choices to use and select halal beauty cosmetic brands is a newly emerging field (Aziz \& Chok, 2013; Teng \& Jamaliah, 2013; Kordnaeij, Askaripoor, \& Bakhshizadeh, 2013; Xiang Meng, 2014; Kaur \& Osman, 2014; Aziz, Wahab, Aziz, \& Aziz, 2014; Ahmad, AbdRahman, \& Ab-Rahman, 2015; Hassali, Al-Tamimi, Dawood, Verma, \& Saleem, 2015; Abd-Rahman, Asrarhaghighi, \& Ab-Rahman, 2015; Abd-Jabar, Ishak, Johar, \& Wahid, 2014; Kawa, Rahmadiani, \& Kumar, 2013; Sutono, 2015; Aisyah, 2015; Kim, Han, Kim, \& Paramita, 2013; Aisyah, 2017).

The literature on the use, selection, intention, perception and practice of halal cosmetic products in Malaysia, Indonesia and Thailand is insufficient. The analysis of articles on halal beauty cosmetics reveals that researchers have paid attention to the halal cosmetic industry in Malaysia, but have substantially ignored the industry in Indonesia and Thailand. The most important aspects of the literature review reveal that behaviours and uses of halal products by Indonesian and Malaysian consumers have not been compared and analysed. Consumers' behaviours, intentions, choices, perceptions and practices related to the use or purchase of halal cosmetic products/brands and preferences for local halal brands over foreign brands have been studied separately in each country. Therefore, this study compares consumers of halal cosmetic products of the three countries and also examines the factors that determine consumers' choices in two countries in their selection of local halal or international non-halal brands. In the above-cited studies, the comparison of domestic and international cosmetic brands concerning halal-ness has also been ignored. 
The significance of this study is its contribution to the academic literature on the rapidly growing fashion and beauty sector in Asian Islamic cultures and the role of small and medium-sized enterprises (SMEs) in spreading popular local notions of beauty through the introduction of local brands. Existing literature on the cosmetics market in Malaysia, for example, explores prospects and future potentials of this industry without examining the socio-religious advantages held by local brands over foreign brands (Hassali et al., 2015; Azmawani Abd. Rahman, Ebrahim Asrarhaghighi, \& Suhaimi Ab. Rahman, 2015; Hashim \& Mat Hashim, 2013; Hussain, Ghani, Mohammad, \& Mehad, 2012). Thus, this paper examines the use of indigenous knowledge and religion (Islam) in brand-building among beauty entrepreneurs in emerging economies of Southeast Asia. Also, the Islamic concepts of halal (clean and pure) and their impacts on the marketability of beauty products are explored.

This paper considers four main objectives:

1) To explain how homegrown beauty companies from Southeast Asian Islamic cultures capitalize on Islamic and indigenous branding strategies;

2) To evaluate if these branding strategies are effective;

3) To describe the similarities and differences in product choice criteria across nations; and

4) To understand customers' choices of foreign products.

\section{Indigenous Branding Strategies}

Traditional knowledge or folk wisdom of the use of herbs for beauty products has been the practice in Malaysia, Indonesia and Thailand for centuries. However, global market penetration has been difficult because of the lack of scientific backing of herbal cosmetic products. In recent years, this market barrier was overcome by a majority of beauty companies that hire professional scientists or chemists. These companies combined their key competencies of halal offerings with indigenous knowledge in building and marketing their products. Cultural-specific branding has emerged as a strategy that these companies can use to compete against imports, as well as to break into world markets. Branding is seen as a crucial factor in distinguishing local products from external competitors, and cultural specificity leverages the uniqueness of the products and their specialized qualities. As the competition in the beauty market for such halal products in the region intensifies, companies in this market cannot rely on religion as a differentiator (Alserhan, 2010) when they 
market their products. These halal companies will have to innovate (Melewar \& Walker, 2003) in order to compete, especially as well-known brands can play catch up and adapt their marketing communications to show they care about the Muslim consumer. As such, traditional indigenous knowledge is capitalized on and purveyed by producers as a kind of 'secret formula,' giving the products competitive advantage and helping to carve out a niche market. Such customer touch points include the halal product status, and these, along with the practice of customer segmentation with a focus on locals as consumers, have allowed these companies to effectively challenge their foreign competitors (Hogan, Almquist, \& Glynn, 2005).

An assumption exists among beauty entrepreneurs in Southeast Asia, as well as their consumers, that their beauty products are halal simply because of the selection of natural products that are used and that the 'cleanliness' and 'purity' of their products are therefore guaranteed. Harnessing indigenous knowledge as an asset that is not owned by multinational companies could be the key differentiator for their businesses. This claim could especially be seen in the Malaysian and Indonesian markets due to indigenous knowledge as a rich cultural and natural heritage. The Malaysian, Indonesian and to a limited degree, Thai beauty industries have also been successful in capitalizing on indigenous knowledge to produce herbal beauty products for local and overseas consumption. Unlike the international competition, most homegrown beauty companies in Malaysia and Indonesia emphasize internal cleansing as part of the overall beauty process. As such, some beauty products are made up of local herbs for ingestion. For Indonesians and Malaysians (including nonMalays), post-natal care has always been an essential element of the concept of overall beauty, both internal and external. In this specific area, the customer touch point of indigenous knowledge is fully utilized by local beauty companies.

\section{Homegrown Beauty Companies}

The management practices of most homegrown beauty companies in Malaysia, Indonesia and Thailand portray typical family firm characteristics (Church, 1993). They are usually owned and managed by their founders, generally women and their family members, and often evolve into medium-sized ventures. These family firms often comprise a parent company with several subsidiaries (both manufacturing and plantation). These firms share the same evolution of a home-based business leveraged on 'word of mouth evangelism' to shop-front business with a bio-network (Simon \& Kotler, 2003) of stockists, distributors and branches spread throughout the country and even across 
borders. These companies begin producing beauty products for local consumption and often later diversify into health food products, emerging more as lifestyle companies (Yacob \& Zainol, 2013).

Most homegrown beauty companies were founded by women who remained active in the management of the companies and internally recruited workers, such that family members held most of the critical positions. These owner-entrepreneurs have strong personalities, were passionate in their business endeavours and determined in their pursuit of success (Reisman, 2004; Schumpeter, 1934). Their entrepreneurial spirit led their companies to evolve from the Avon or Amway style of door-to-door sales into lifestyle companies.

Muslim women in the Southeast Asian region have greater participation in all social and economic activities and have more purchasing power (Sayyed, 2017). "Old" Indonesian brands such as Mustika Ratu, Sari Ayu, Nyonya Meneer, Martha Tilaar, and "new" brands such as Wardah and Purbasari were all founded by women. The same could be said of Malaysian homegrown beauty companies such as NR, Sendayu Tinggi, Natasya, Tanamera, Jerneh and Taharah (Horizon, 2018). In Malaysia, more than a dozen beauty brands are owned by Malaysian women (Chan, 2017). In Thailand, most local beauty brands such as Oriental Princess, Mistine as well as the halal beauty brand Pimmara, were established by women (Horizon, 2018).

\section{Cultural-Religious Symbols}

Nusantara is an area covering the Malay Archipelago. Its rich history and culture have often been claimed by competing for Indonesian beauty products such as Mustika Ratu, Sari Ayu and Martha Tilaar. These products have dominated the Malay beauty market in Malaysia since the early 1970s. Companies like NR, Sendayu Tinggi, Natasya and Tanamera expertly made use of history and tradition linked to Nusantara's health and beauty legacy in order to establish their brand images. NR's new slogan, 'because only nature is NR's choice', underscores its core values of indigenous herbal knowledge, and like many modern beauty companies, recently attempted to suggest 'green' credentials. Its corporate colours are green (symbolizing Islamic values, nature and freshness) and royal yellow. Its logo is a royal symbol from ancient kingdoms in the Nusantara area reinforcing notions of cultural heritage, traditional health practices and beauty secrets inherited from the past.

The beauty company Tanamera, on the other hand, capitalizes on its product uniqueness through the company's use of tropical herbs derived from 
the rich tropical forest indigenous to the region. In comparison, Taharah combines the use of clay and seaweed in its beauty products. The species of eucyma (seaweed) grows in the coastal area of Semporna, Sabah and are used by Bajau (indigenous ethnic group in Sabah, Malaysia) women for skincare and health purposes.

Other than an emphasis on natural products, some of these companies also mention the term 'halal' in their taglines. For example, the company Jerneh's tagline is 'pure, halal and safe'. Taharah derived its brand name from the Arabic word, Tahara, a necessary cleansing procedure Muslims undertake after coming in contact with any forbidden elements/entities. This condition reflects the Muslim belief in the concept of cleansing and purity. Other homegrown companies in Malaysia, such as Natasya, carry a logo of the mehrab or private prayer sanctuary and similarly used green as its corporate colour.

Figure 1: Brand ambassadors of beauty products in Asian Islamic Cultures

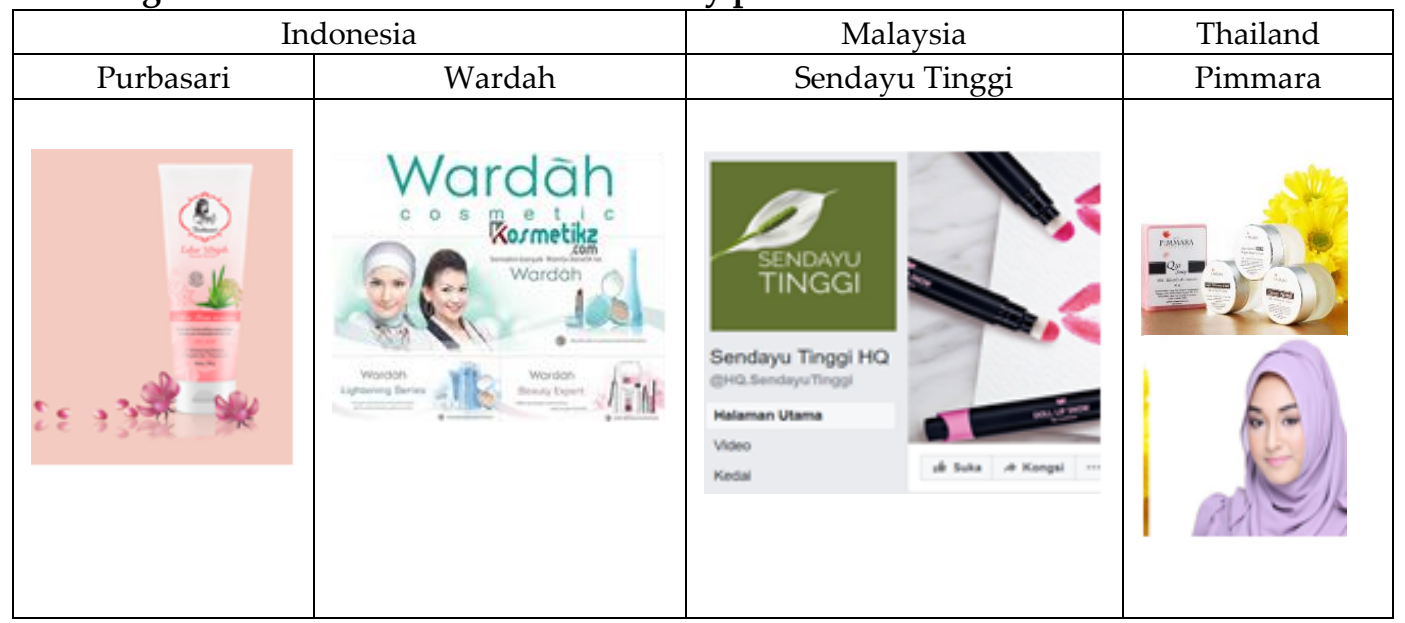

Sources: Horizon (2018); Purbasari (2018); Sendayu Tinggi (2018); Wardah Cosmetic (2018).

In contrast, "old" beauty brand names in Indonesia prefer to play on its history and heritage. This includes the use of tropical herbs, but unlike Malaysian companies that used the green elements of nature in their logos, Indonesian beauty companies, such as Mustika Ratu, Sari Ayu and Martha Tilaar, use the portraits of the quintessential $I b u$ or mother grace the paper packets of jamu or traditional herbal remedies and the bottles of herbal-based lotions and creams. However, for new or recently established beauty firms from the late 1980s until early 2000s, Malaysians and Indonesians prefer to 
portray their young brand ambassadors in Islamic dress, suggesting that while the products may formerly have been more conservative and aimed at mothers, they are now also appealing to a younger, more fashion conscious generation. For Pimmara in Thailand, the brand name and the brand ambassador is the young founder herself, Pimmara Seedokbuab who dons the hijab (head covering worn by Muslim women in public). Nonetheless, there are some brand names such as Wardah that have brand ambassadors with and without the headscarf (see Figure 1).

\section{Methodology}

A questionnaire survey was carried out with 600 female respondents randomly chosen at various locations including beauty companies' offices and beauty shops in shopping malls in Jakarta (Indonesia), Kuala Lumpur (Malaysia) and Bangkok (Thailand), with 361 completed surveys. The questionnaire survey tool was used to learn about female consumers' choices in the industry including their reasons for choosing certain beauty brands and if they were influenced by the concepts of "halal-ness" and indigenous knowledge used by the local companies, or had other factors such as suitability and quality. The survey contained more than 100 questions mostly close-ended. However, some questions were open-ended in order to gain respondents' points of view. Their points of view primarily help to develop a better understanding of consumers' choices in two countries. Table 1 shows the details of the questionnaire contents.

Table 1: Details of questionnaire contents

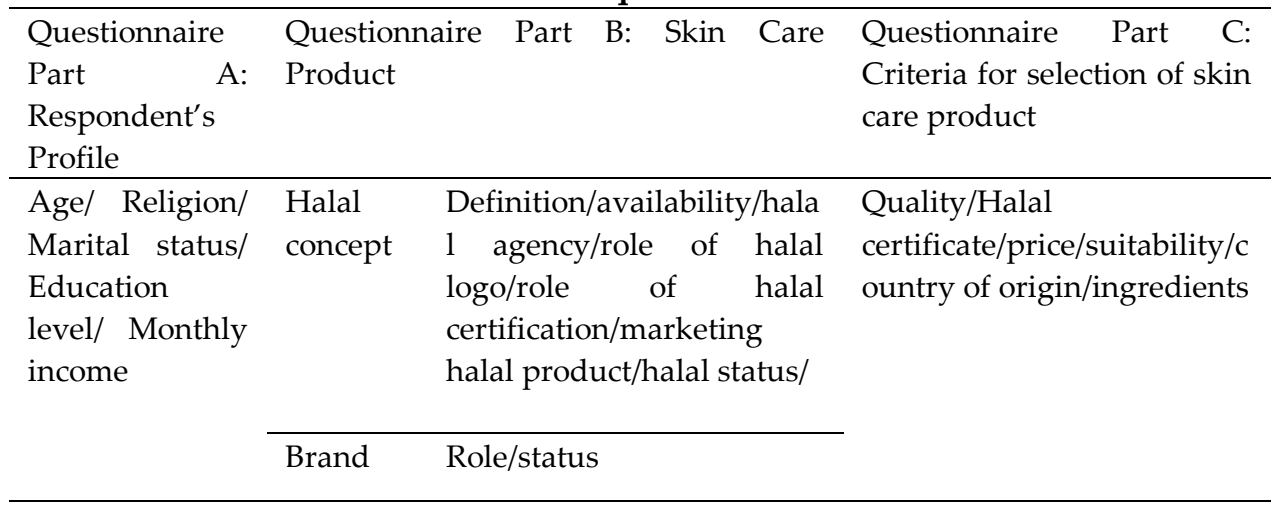

In total, 361 questionnaire surveys, carried out at various locations namely offices and shopping malls, were returned with complete information. 
Table 1.1: Background information of local companies chosen for the survey

\begin{tabular}{|c|c|c|}
\hline $\begin{array}{l}\text { Brand's } \\
\text { Country of } \\
\text { Origin }\end{array}$ & Brand & Background information \\
\hline \multirow{7}{*}{ Malaysia } & Nona Roguy & $\begin{array}{l}\text { Nona Roguy is famous for producing herbal creams, } \\
\text { drinks and capsules for the post-natal care of women, } \\
\text { and delivers its products to buyers from any part of the } \\
\text { world. }\end{array}$ \\
\hline & Safi & $\begin{array}{l}\text { SAFI produces skincare, personal care and toiletry } \\
\text { products to meet the needs of Muslim women and } \\
\text { men. }\end{array}$ \\
\hline & Natasha & $\begin{array}{l}\text { Natasha provides treatment for men and women's skin } \\
\text { and hair and produces different products for this } \\
\text { purpose. }\end{array}$ \\
\hline & Sendayu Tinggi & $\begin{array}{l}\text { Sendayu Tinggi produces herbal products for women's } \\
\text { skincare. }\end{array}$ \\
\hline & Dunia Herbs & $\begin{array}{l}\text { Dunia Herbs provides herbal beauty and health } \\
\text { products. }\end{array}$ \\
\hline & Shurah & $\begin{array}{l}\text { Shurah offers certified personal care products, which } \\
\text { include facial skins care products, hair, body, facial } \\
\text { makeup and fragrance products. }\end{array}$ \\
\hline & Simply Siti & $\begin{array}{l}\text { Simply Siti is a local brand and maintains local } \\
\text { identity. It offers cosmetic, skin care and fragrance } \\
\text { products. }\end{array}$ \\
\hline \multirow{8}{*}{ Indonesia } & PAC & $\begin{array}{l}\text { PAC provides a wide range of herbal and modern skin } \\
\text { care, fragrance, hair care and body care products. }\end{array}$ \\
\hline & Purbasari & $\begin{array}{l}\text { Gloria Origita is a cosmetic company that produces } \\
\text { purbasari bath scrub, Cana leg cream, New Cell face } \\
\text { cream, Amara sprays cologne, body scrub, and teeth } \\
\text { whitener Softwhite, Freya decorative series, Cleanface } \\
\text { face cleanser, which has been marketed all over } \\
\text { Indonesia. }\end{array}$ \\
\hline & Viva & $\begin{array}{l}\text { Viva offers cosmetics and perfume products and } \\
\text { services. }\end{array}$ \\
\hline & Biokos & $\begin{array}{l}\text { Biokos provides many skin care products made up of } \\
\text { natural ingredients. }\end{array}$ \\
\hline & Ristra & $\begin{array}{l}\text { Ristra produces and sales products for skin care, hair } \\
\text { care and makeup. }\end{array}$ \\
\hline & Wardah & $\begin{array}{l}\text { Wardah specializes in cosmetic products and creams } \\
\text { for skin care. }\end{array}$ \\
\hline & Sari Ayu & $\begin{array}{l}\text { Sari Ayu offers a wide range of beauty and skin care } \\
\text { products made from local ingredients. }\end{array}$ \\
\hline & Mustika Ratu & $\begin{array}{l}\text { Mustika Ratu produces a wide range of cosmetic } \\
\text { ingredients. }\end{array}$ \\
\hline
\end{tabular}


Oriental Princess Oriental Princess provides various skin and hair care products for men and women.

Mistine Mistine produces 5,000 cosmetic products for skin care, makeup, body care, fragrance and personal care.

The companies listed in Table 1.1 have successfully retained local cosmetic and skin care, body care and fragrance markets in their respective countries. These companies were selected randomly and were based on homegrown companies, indigenous ingredients and halal certification criteria. The list of international companies was randomly selected based on their popularity.

\section{Results}

\section{Respondents' profiles}

From the survey conducted, about $33.5 \%(\mathrm{n}=121)$ of the respondents were Malaysians, 34.3\% ( $n=124)$ Indonesians and $32.1 \%(n=116)$ Thais. Of the total respondents, $65.4 \%$ were below 24 years of age, $25.7 \%$ between $25-34$ years old, $5.4 \%$ and $3.4 \%$ between $35-44$ years of age and above 45 years old respectively. Most of the respondents (84.8\%) were Muslims followed by Buddhists (14.4\%) and Christians (0.3\%). Regarding marital status, most respondents were single $(76.9 \%)$ followed by married (20.9\%) and divorced/widow (2.2\%). Most respondents had a certificate/diploma/degree/master/PhD degree $(77.4 \%)$ and earned a monthly income of less than RM 5000 (86.8\%) per month.

\section{Knowledge and understanding of halal cosmetics}

Respondents were asked about their understanding of the halal or tayyibah concept. The meaning of tayyibah was only understood by $52.1 \%$ of the total respondents with Indonesians ranking the highest $(75.8 \%)$, followed by Malaysians (52.1\%) and Thais (26.7\%). Most of the Indonesians (79\%) and Malaysians $(70.2 \%)$ in the survey were aware of the availability of halal products in the market. For the majority of Indonesian respondents, understanding the concept of halal was essential. As Muslims, they wanted to know the halal and haram ingredients in the products and also for the sake of gaining knowledge. Additionally, a large number of respondents claimed that since Indonesia was a Muslim country, all Muslims should know halal and haram ingredients. A few respondents hinted that Muslims must clearly understand the difference between halal and haram and then promote it. One woman said that when she uses halal products her face would be smooth and clean. Another woman said that she was more satisfied with halal products. 
Some of the respondents were concerned that putting a logo on the cosmetic product did not guarantee that a product was halal because many companies were putting the logo on uncertified products.

In Malaysia, the majority of respondents believed that even nonMuslims had an understanding of halal cosmetics. Thus, many non-Muslim females preferred not to buy and use halal cosmetic products. However, they said that most Muslim girls and women used products with the halal logo. For the majority of respondents, a halal product with a halal logo was easier to convince consumers. Some respondents added that halal products were used as a guarantee that consumers would have benefits and that they would not contain any kind of haram (prohibited) ingredients. Another respondent said that a cosmetic product with banned ingredients is not only dangerous for health and skin but also unacceptable during prayer times. Some respondents said that Muslims worry about halal and haram ingredients in cosmetic products because after the use of haram products their prayers would not be accepted. One respondent added that having halal products not only increased the confidence of consumers but also encouraged producers because Muslims would buy halal products and prefer halal over non-halal products. In Thailand, some of the Muslim respondents suggested that they have an understanding of the concept of halal, but many said that it did not make a difference to have this understanding because the local brands used harmless ingredients. Table 2 shows the details of the agreement.

Table 2: Agreement on the concept and awareness of the availability of halal products

\begin{tabular}{|c|c|c|c|c|c|c|c|}
\hline \multirow[b]{2}{*}{ Statement } & \multirow[b]{2}{*}{ Agreemen } & \multicolumn{3}{|l|}{ Country } & \multirow[b]{2}{*}{ Total } & \multirow{2}{*}{$\begin{array}{l}\text { Chi- } \\
\text { square }\end{array}$} & \multirow{2}{*}{$\begin{array}{l}\text { Significant } \\
\text { value } \\
\text { value })\end{array}$} \\
\hline & & $\begin{array}{l}\text { Malaysia } \\
(\mathrm{n}=121)\end{array}$ & $\begin{array}{l}\text { Indonesia } \\
(\mathrm{n}=124)\end{array}$ & $\begin{array}{l}\text { Thailand } \\
(\mathrm{n}=116)\end{array}$ & & & \\
\hline \multirow{2}{*}{$\begin{array}{l}\text { Definition } \\
\text { of Tayyibah }\end{array}$} & Yes & $52.1 \%$ & $75.8 \%$ & $26.7 \%$ & $52.1 \%$ & \multirow{2}{*}{57.853} & \multirow{2}{*}{0.000} \\
\hline & No & $47.9 \%$ & $24.2 \%$ & $73.3 \%$ & $47.9 \%$ & & \\
\hline \multirow{3}{*}{\multicolumn{2}{|c|}{$\begin{array}{l}\text { Awareness Yes } \\
\text { of the Not sure } \\
\text { availability } \\
\text { of halal No } \\
\text { products }\end{array}$}} & $70.2 \%$ & $79.0 \%$ & $9.5 \%$ & $53.7 \%$ & \multirow{3}{*}{163.264} & \\
\hline & & $24.0 \%$ & $20.2 \%$ & $44.0 \%$ & $29.1 \%$ & & 0.000 \\
\hline & & $5.8 \%$ & $.8 \%$ & $46.6 \%$ & $17.2 \%$ & & \\
\hline
\end{tabular}

Respondents were also asked about their understanding of what is required for products to be halal. All respondents agreed that halal products should consist of natural ingredients $(66.4 \%)$, herbal ingredients $(66.4 \%)$ or indigenous 
ingredients $(43.3 \%)$. Halal products should not use alcohol $(70.4 \%)$, animal placenta $(59.3 \%)$, human placenta $(76.6 \%)$ and any animal body parts $(58.4 \%)$. From crosstab analysis, what is found is that Malaysians placed more emphasis on no alcohol (82.6\%), while Indonesians $(81.5 \%)$ and Thais $(66.7 \%)$ said no to the animal placenta. Nevertheless, Malaysians (58.3\%) and Thais $(8.6 \%)$ similarly shared the lowest percentage on the statement that contained indigenous ingredients. Table 3 shows the detail of respondents' agreements on these statements.

Table 3: Details of respondents' agreements on statements related to the requirements of a halal product

\begin{tabular}{|c|c|c|c|c|c|c|c|}
\hline \multirow[b]{2}{*}{ Statement } & \multirow[b]{2}{*}{ Agreement } & \multicolumn{2}{|l|}{ Country } & \multirow[b]{2}{*}{$\begin{array}{l}\text { Thailand } \\
(n=116)\end{array}$} & \multirow[b]{2}{*}{ Total } & \multirow[b]{2}{*}{ Chi-square } & \multirow{2}{*}{$\begin{array}{l}\text { Significant } \\
\text { value } \quad(p- \\
\text { value })\end{array}$} \\
\hline & & $\begin{array}{l}\text { Malaysia } \\
(\mathrm{n}=121)\end{array}$ & $\begin{array}{l}\text { Indonesia } \\
(\mathrm{n}=124)\end{array}$ & & & & \\
\hline \multirow{3}{*}{ No alcohol } & Yes & $82.6 \%$ & $66.9 \%$ & $61.2 \%$ & $70.4 \%$ & \multirow{3}{*}{30.519} & \multirow{3}{*}{0.000} \\
\hline & Not sure & $7.4 \%$ & $30.6 \%$ & $25.0 \%$ & $21.1 \%$ & & \\
\hline & No & $9.9 \%$ & $2.4 \%$ & $13.8 \%$ & $8.6 \%$ & & \\
\hline \multirow{3}{*}{$\begin{array}{l}\text { No animal } \\
\text { placenta }\end{array}$} & Yes & $75.2 \%$ & $66.9 \%$ & $34.5 \%$ & $59.3 \%$ & \multirow{3}{*}{48.247} & \multirow{3}{*}{0.000} \\
\hline & Not sure & $19.8 \%$ & $29.0 \%$ & $49.1 \%$ & $32.4 \%$ & & \\
\hline & No & $5.0 \%$ & $4.0 \%$ & $16.4 \%$ & $8.3 \%$ & & \\
\hline \multirow{3}{*}{$\begin{array}{l}\text { No human } \\
\text { placenta }\end{array}$} & Yes & $81.0 \%$ & $81.5 \%$ & $66.7 \%$ & $76.6 \%$ & \multirow{3}{*}{11.136} & \multirow{3}{*}{0.025} \\
\hline & Not sure & $16.5 \%$ & $15.3 \%$ & $24.6 \%$ & $18.7 \%$ & & \\
\hline & No & $2.5 \%$ & $3.2 \%$ & $8.8 \%$ & $4.7 \%$ & & \\
\hline \multirow{3}{*}{$\begin{array}{l}\text { No animal } \\
\text { part }\end{array}$} & Yes & $72.9 \%$ & $58.2 \%$ & $44.0 \%$ & $58.4 \%$ & \multirow{3}{*}{20.294} & \multirow{3}{*}{0.000} \\
\hline & Not sure & $22.0 \%$ & $35.2 \%$ & $47.4 \%$ & $34.8 \%$ & & \\
\hline & No & $5.1 \%$ & $6.6 \%$ & $8.6 \%$ & $6.7 \%$ & & \\
\hline \multirow{3}{*}{$\begin{array}{l}\text { Contains } \\
\text { natural } \\
\text { ingredients }\end{array}$} & Yes & $71.7 \%$ & $76.0 \%$ & $50.9 \%$ & $66.4 \%$ & \multirow{3}{*}{25.696} & \multirow{3}{*}{0.000} \\
\hline & Not sure & $13.3 \%$ & $19.8 \%$ & $29.3 \%$ & $20.7 \%$ & & \\
\hline & No & $15.0 \%$ & $4.1 \%$ & $19.8 \%$ & $12.9 \%$ & & \\
\hline \multirow{3}{*}{$\begin{array}{l}\text { Contains } \\
\text { herbal } \\
\text { ingredients }\end{array}$} & Yes & $63.3 \%$ & $69.4 \%$ & $35.3 \%$ & $56.4 \%$ & \multirow{3}{*}{36.981} & \multirow{3}{*}{0.000} \\
\hline & Not sure & $20.0 \%$ & $25.0 \%$ & $40.5 \%$ & $28.3 \%$ & & \\
\hline & No & $16.7 \%$ & $5.6 \%$ & $24.1 \%$ & $15.3 \%$ & & \\
\hline \multirow{3}{*}{$\begin{array}{l}\text { Contains } \\
\text { indigenous } \\
\text { ingredients }\end{array}$} & Yes & $58.3 \%$ & $61.3 \%$ & $8.6 \%$ & $43.3 \%$ & \multirow{3}{*}{92.171} & \multirow{3}{*}{0.000} \\
\hline & Not sure & $23.3 \%$ & $31.5 \%$ & $51.7 \%$ & $35.3 \%$ & & \\
\hline & No & $18.3 \%$ & $7.3 \%$ & $39.7 \%$ & $21.4 \%$ & & \\
\hline
\end{tabular}

Table 3 shows that a good number of respondents in the three countries either had no knowledge or did not agree with the statements. For instance, in Malaysia, out of 121 respondents, $7.4 \%$ of the respondents were not sure if a product was halal (pure) without alcohol while $9.9 \%$ of the respondents 
believed that alcohol did not make a product non-halal (impure). In Indonesia, $30.6 \%$ of the respondents were not sure whether alcohol made a product haram (non-halal) or not while $2.4 \%$ said that with alcohol, a product did not become haram (impure). In Thailand, the number of respondents was a bit higher $(13.8 \%)$ for those who believed that alcohol did not make the product haram while $25 \%$ of the respondents were not sure about it.

In Malaysia, $19.8 \%$ and $16.5 \%$ of the respondents did not know if animal placenta and human placenta made a product impure (non-halal) while $5 \%$ and $2.5 \%$ of the respondents said that animal and human placenta respectively did not make the product impure (non-halal). In Thailand, the number of respondents $(49.1 \%$ and $24.6 \%)$ was higher for those who did not know that with animal and human placenta, a product became impure (nonhalal). On the other hand, $16.4 \%$ and $8.8 \%$ of respondents categorically said that animal and human placenta did not make products impure (non-halal).

With regards to awareness about agencies that issue halal certification, the majority of the respondents were aware of each their own country's certifying agency: The Central Islamic Council of Thailand for Thailand (94.8\%), Majelis Ulama Indonesia (MUI) for Indonesia (92.7\%) and JAKIM for Malaysia (92.6\%). Furthermore, the Halal Development Corporation $(3.3 \%)$ was accepted in all three countries. Malaysians and Indonesians also acknowledged JAKIM (31.3\%). Table 4 shows the details of the percentage.

Table 4: Halal certificate agencies

\begin{tabular}{|c|c|c|c|c|c|c|}
\hline \multirow[b]{2}{*}{ Halal certificate agencies } & \multicolumn{3}{|l|}{ Country } & \multirow[b]{2}{*}{ Total } & \multirow{2}{*}{$\begin{array}{l}\text { Chi- } \\
\text { square }\end{array}$} & \multirow{2}{*}{$\begin{array}{l}\text { Significant } \\
\text { level } \\
\text { value })\end{array}$} \\
\hline & $\begin{array}{l}\text { Malaysia } \\
(\mathrm{n}=121)\end{array}$ & $\begin{array}{l}\text { Indonesia } \\
(\mathrm{n}=124)\end{array}$ & $\begin{array}{l}\text { Thailand } \\
(\mathrm{n}=116)\end{array}$ & & & \\
\hline JAKIM & $92.6 \%$ & $.8 \%$ & $.0 \%$ & $31.3 \%$ & & \\
\hline Development & $7.4 \%$ & $.8 \%$ & $1.7 \%$ & $3.3 \%$ & & \\
\hline $\begin{array}{l}\text { The Central Islamic Council of } \\
\text { Thailand }\end{array}$ & $.0 \%$ & $.0 \%$ & $94.8 \%$ & $30.5 \%$ & 701.589 & 0.000 \\
\hline Majelis Ulama Indonesia (MUI) & $.0 \%$ & $92.7 \%$ & $.0 \%$ & $31.9 \%$ & & \\
\hline $\begin{array}{l}\text { Badan Pengawas Obat dan } \\
\text { Makanan (BPOM) }\end{array}$ & $.0 \%$ & $5.6 \%$ & $.0 \%$ & $1.9 \%$ & & \\
\hline Others & $.0 \%$ & $.0 \%$ & $3.4 \%$ & $1.1 \%$ & & \\
\hline
\end{tabular}

Regarding the halal logo, each country has its own halal logo. Asked whether the halal logo played a significant role in the marketing of beauty products, out of a total of 361 respondents, $60.3 \%$ said yes. Malaysians (78.1\%) along 
with their counterparts in Indonesia (66\%) agreed with the statement. Of the 361 respondents, there were still $31.2 \%$ who said that they were not sure if the halal logo played a role, while $8.5 \%$ denied any such role of the logo, a majority of who were Thai respondents (16\%). More than $60 \%$ of the respondents thought that the halal status played an important role in marketing. Among these respondents, the most yes responses (84.9\%) came from Malaysians followed by Indonesians (66.9\%) and Thais (10\%). 5.3\% of Malaysians, $4.1 \%$ of Indonesians and $16 \%$ of Thais noted that the halal logo did not play any role in the marketing of beautifying products while $5 \%$ of Malaysians, $11.3 \%$ of Indonesians and $13.8 \%$ of Thais said that the halal status was of no importance to the beauty products. Thai respondents (50.9\%), however, were not sure whether halal certification would bring any impact to marketing. Tab1e 5 shows the crosstab analysis between the role and status of the halal logo according to country. The results suggest that religious logos in religious communities significantly contribute to occupying space in the consumer market (Majid et al., 2015, Shaari et al., 2014).

Table 5: Halal logo and status in marketing beauty products

\begin{tabular}{|c|c|c|c|c|c|c|}
\hline & \multicolumn{3}{|l|}{ Country } & \multirow[b]{2}{*}{ Total } & \multirow{2}{*}{$\begin{array}{l}\text { Chi- } \\
\text { Square }\end{array}$} & \multirow{2}{*}{$\begin{array}{l}\text { Significant } \\
\text { level ( } p \text { - } \\
\text { value) }\end{array}$} \\
\hline & $\begin{array}{l}\text { Malaysia } \\
(\mathrm{n}=121)\end{array}$ & $\begin{array}{l}\text { Indonesia } \\
(\mathrm{n}=124)\end{array}$ & $\begin{array}{l}\text { Thailand } \\
(\mathrm{n}=116)\end{array}$ & & & \\
\hline \multirow{3}{*}{$\begin{array}{l}\text { Halal } \log 0 \\
\text { play a role in } \\
\text { marketing }\end{array}$} & $78.1 \%$ & $66.0 \%$ & $35.8 \%$ & $60.3 \%$ & \multirow{3}{*}{45.138} & \multirow{3}{*}{.000} \\
\hline & $16.7 \%$ & $29.9 \%$ & $48.1 \%$ & $31.2 \%$ & & \\
\hline & $5.3 \%$ & $4.1 \%$ & $16.0 \%$ & $8.5 \%$ & & \\
\hline \multirow{3}{*}{$\begin{array}{l}\text { Importance } \\
\text { halal status }\end{array}$} & $84.9 \%$ & $66.9 \%$ & $35.3 \%$ & $62.7 \%$ & \multirow{3}{*}{66.226} & \multirow{3}{*}{.000} \\
\hline & $10.1 \%$ & $21.8 \%$ & $50.9 \%$ & $27.3 \%$ & & \\
\hline & $5.0 \%$ & $11.3 \%$ & $13.8 \%$ & $10.0 \%$ & & \\
\hline
\end{tabular}

\section{Determining Factors in Selecting Brands}

This study also examines the role played by brands and whether or not users were keen to buy foreign/international products. The findings reveal that of the total 361 respondents from all three countries, only $13 \%$ said that branding played a role in affecting their choice of selecting a beauty product; $41 \%$ respondents were not sure and $43.3 \%$ rejected the role of branding in influencing their decision of choosing beauty products. 
Table 6: Role of branding in beauty product selection

\begin{tabular}{|c|c|c|c|c|c|c|c|}
\hline \multirow[t]{2}{*}{ Brand } & & \multicolumn{3}{|l|}{ Country } & \multirow[b]{2}{*}{ Total } & \multirow[b]{2}{*}{ Chi-Square } & \multirow[b]{2}{*}{ Significant level ( $p$-value) } \\
\hline & & $\begin{array}{l}\text { Malaysia } \\
(\mathrm{n}=121)\end{array}$ & $\begin{array}{l}\text { Indonesia } \\
(\mathrm{n}=124)\end{array}$ & $\begin{array}{l}\text { Thailand } \\
(\mathrm{n}=116)\end{array}$ & & & \\
\hline \multirow[t]{3}{*}{ Role of brand } & Yes & $14.9 \%$ & $15.5 \%$ & $8.6 \%$ & $13.0 \%$ & & \\
\hline & Not sure & $30.7 \%$ & $57.7 \%$ & $39.0 \%$ & $41.8 \%$ & 22.384 & .000 \\
\hline & No & $54.4 \%$ & $26.8 \%$ & $52.4 \%$ & $45.3 \%$ & & \\
\hline \multirow[t]{3}{*}{ Local brand } & Yes & $36.3 \%$ & $22.4 \%$ & $1.9 \%$ & $20.5 \%$ & & \\
\hline & Not sure & $48.7 \%$ & $75.5 \%$ & $62.3 \%$ & $61.5 \%$ & 71.191 & 0.000 \\
\hline & No & $15.0 \%$ & $2.0 \%$ & $35.8 \%$ & $18.0 \%$ & & \\
\hline \multirow[t]{3}{*}{ Foreign brand } & Yes & $15.9 \%$ & $6.3 \%$ & $30.2 \%$ & $17.8 \%$ & & \\
\hline & Not sure & $56.6 \%$ & $84.2 \%$ & $49.1 \%$ & $62.4 \%$ & 35.747 & 0.000 \\
\hline & No & $27.4 \%$ & $9.5 \%$ & $20.8 \%$ & $19.7 \%$ & & \\
\hline
\end{tabular}

The majority of the participants from all three countries were not sure whether local branding $(61.5 \%)$ or foreign branding $(62.5 \%)$ played any role in influencing their choice in buying a beauty product. In Malaysia, $36.3 \%$ and $15.9 \%$, said that local branding and foreign branding respectively played a role in shaping their choices. Only $15 \%$ and $27.4 \%$ of respondents said that local and foreign brands respectively had not influenced their choices. Overall, the results show that local and international branding had little impact on the respondents' choices in selecting beauty products.

\section{Product Selection Criteria}

In examining the factors that may contribute to the selection of a product by users, respondents were asked to rate their main criteria by level of importance when selecting beauty products for use. The relative importance index analysis was used to measure the criteria. Findings show that Malaysians' scores of importance on all criteria were above average. This result is followed by Indonesians who ranked five out of six criteria above the mean scores. Thais, however, only had one score above average and the rest were below the mean scores of the three countries. In general, Malaysians put more importance on suitability (0.908) followed by quality (0.899). Halal certification (0.862) falls third; the ingredients in the products (0.875) ranked as fourth and country of origin (0.729) came in last. All these scores are above average. Indonesians, on the other hand, put more importance on quality (0.909), followed by suitability (0.891). Similar to Malaysians, they ranked halal certification (0.850) third and product ingredients $(0.837)$ fourth. The Thais also ranked quality $(0.866)$ as the most important criterion. However, Thais labeled product ingredients (0.751) as more important than suitability (0.741) and halal certification (0.546) as the 
third least important in their product selections. Remarkably, the country of origin plays the least important of all the criteria in the respondents' product selections. Table 7 shows the scores of the relative importance index for selection criteria.

Table 7: Relative importance index on product selection criteria

\begin{tabular}{lllll}
\hline \multirow{2}{*}{ Criteria } & Mean & \multicolumn{2}{c}{ Country } \\
\cline { 3 - 5 } & & $\begin{array}{l}\text { Malaysia } \\
(\mathrm{n}=121)\end{array}$ & $\begin{array}{l}\text { Indonesia } \\
(\mathrm{n}=124)\end{array}$ & $\begin{array}{l}\text { Thailand } \\
(\mathrm{n}=116)\end{array}$ \\
\hline Quality & 0.891 & 0.899 & 0.909 & 0.866 \\
Suitability & 0.847 & 0.908 & 0.891 & 0.741 \\
Ingredient & 0.821 & 0.875 & 0.837 & 0.751 \\
Halal certificate & 0.753 & 0.862 & 0.850 & 0.546 \\
Price & 0.748 & 0.786 & 0.761 & 0.698 \\
Country of origin & 0.609 & 0.729 & 0.593 & 0.506 \\
\hline
\end{tabular}

From these analyses, it is found that brand name does not only play a significant role in the selection of a beauty product, whereas quality $(X=0.891)$, suitability $(X=0.847)$, product ingredients $(X=0.821)$ and halal certification $(X=0.753)$ are the top four factors that influence a beauty user's product selection. As mentioned earlier, although Indonesia has the highest number of Muslims as compared to the other two countries, halal certification ranked third in its users' product selections. For Malaysians, halal certification ranked fourth which is similar to that of the Thais, even though the latter country has a Muslim minority. Interestingly, Thai respondents choose quality and product ingredients rather than suitability as their top two priorities. This finding shows a significant advantage of beauty products having indigenous ingredients in the Thai market and is contrary to the statement made by Cayla and Arnould (2008) who claim Asian beauty products lack authentic brands. The results demonstrate that beauty product users preferred local products but they had specific criteria. The criterion of halal certification was not as important as quality, suitability and types of ingredients used in beauty products. However, a respondent added that if a product met the first two criteria and did not meet the halal criterion, they would drop the product even if the product suited them and its quality is excellent. The researchers suggest that this kind of consumer response indicates that consumers would not buy halal products if they are not suitable nor good in quality. This implies that halal certification matters a lot for consumers even if these meet the priority criteria.

Table 8 reveals that the local brands of beauty products were preferred and used within the country and had less success outside of the country of 
origin. For instance, all beauty brands that are popular in Malaysia were mentioned by Malaysian respondents. Similarly, Thai and Indonesian respondents did not mention names of any of the brands from other countries. In Thailand, halal beauty products produced by Pimmara failed to secure a large user base compared with its counterparts like Oriental Princess and Mistine (see Table 8).

Table 8: Beauty users of local brands in Malaysia, Indonesia, and Thailand

\begin{tabular}{|c|c|c|c|c|c|c|}
\hline $\begin{array}{l}\text { Brand's } \\
\text { Country } \\
\text { of Origin }\end{array}$ & Brand & Malaysia & Indonesia & Thailand & $\begin{array}{l}\text { Chi- } \\
\text { square }\end{array}$ & $\begin{array}{l}p \text { - } \\
\text { value }\end{array}$ \\
\hline \multirow{7}{*}{ Malaysia } & Nona & $100 \%(5)$ & $.0 \% \quad(0)$ & $.0 \% \quad(0)$ & 9.046 & .011 \\
\hline & Safi & $\begin{array}{l}100.0 \% \\
(54)\end{array}$ & $.0 \%(0)$ & $.0 \%(0)$ & 115.901 & .000 \\
\hline & Natasha & $\begin{array}{l}100.0 \% \\
(10)\end{array}$ & $.0 \%(0)$ & $.0 \%(0)$ & 18.387 & .000 \\
\hline & $\begin{array}{l}\text { Sendayu } \\
\text { Tinggi }\end{array}$ & $100.0 \%(9)$ & $.0 \%(0)$ & $.0 \%(0)$ & 16.495 & .000 \\
\hline & $\begin{array}{l}\text { Dunia } \\
\text { Herbs }\end{array}$ & $100.0 \%$ & $.0 \%(0)$ & $.0 \%(0)$ & 16.495 & .000 \\
\hline & Shurah & $\begin{array}{l}100.0 \% \\
(22)\end{array}$ & $.0 \%(0)$ & $.0 \%(0)$ & 42.097 & .000 \\
\hline & Simply Siti & $\begin{array}{l}100.0 \% \\
(12)\end{array}$ & $.0 \%(0)$ & $.0 \%(0)$ & 22.209 & .000 \\
\hline \multirow{8}{*}{ Indonesia } & PAC & $.0 \%(0)$ & $100.0 \%(11)$ & $.0 \%(0)$ & 25.845 & .000 \\
\hline & Purbasari & $.0 \%(0)$ & $100.0 \%(18)$ & $.0 \%(0)$ & 43.282 & .000 \\
\hline & Viva & $.0 \%(0)$ & $100.0 \%(20)$ & $.0 \%(0)$ & 48.415 & .000 \\
\hline & Biokos & $.0 \%(0)$ & $100.0 \%$ & $.0 \%(0)$ & 6.869 & .032 \\
\hline & Ristra & $.0 \%(0)$ & $100.0 \%(7)$ & $.0 \%(0)$ & 16.235 & .000 \\
\hline & Wardah & $.0 \%(0)$ & $100.0 \%$ & $.0 \%(0)$ & 147.621 & .000 \\
\hline & Sari Ayu & $.0 \%(0)$ & $100.0 \%$ & $.0 \%(0)$ & 66.938 & .000 \\
\hline & $\begin{array}{l}\text { Mustika } \\
\text { Ratu }\end{array}$ & $.0 \%(0)$ & $100.0 \%(31)$ & $.0 \%(0)$ & 77.930 & .000 \\
\hline \multirow{4}{*}{ Thailand } & Pimmara & $.0 \%(0)$ & $.0 \%(0)$ & $100.0 \%(6)$ & 12.174 & .002 \\
\hline & Oriental & $.0 \%(0)$ & $.0 \%(0)$ & $100.0 \%$ & 101.701 & .000 \\
\hline & Princess & & & $(44)$ & & \\
\hline & Mistine & $.0 \%(0)$ & $.0 \%(0)$ & $\begin{array}{l}100.0 \% \\
(29)\end{array}$ & 63.539 & .000 \\
\hline
\end{tabular}

In contrast, foreign brands managed to penetrate into the beauty sectors in all three countries with Johnson \& Johnson enjoying a high number of respondents in Malaysia (60.2\%) followed by Indonesia (39.8\%) but not in Thailand. The high usage is due to factors that Johnson \& Johnson not only 
makes quality products but also uses the halal logo to attract Muslim users in both Malaysia and Indonesia. In Thailand, Vaseline (100\%) and Nivea $(89.3 \%)$ seemed popular among the respondents (see Table 9).

Table 9: Beauty users of foreign brands in Malaysia, Indonesia, and Thailand

\begin{tabular}{llllll}
\hline Brand & Malaysia & Indonesia & Thailand & Chi-square & $\begin{array}{l}p \text { - } \\
\text { value }\end{array}$ \\
\hline Body shop & $50 \%(36)$ & $20.8 \%(15)$ & $29.2 \%(21)$ & 8.517 & .014 \\
L'Oreal & $31.5 \%(23)$ & $19.2 \%(14)$ & $49.3 \%(36)$ & 11.716 & .003 \\
Estee Lauder & $21.1 \%$ & $5.3 \%(1)$ & $73.7 \%(14)$ & 15.280 & .000 \\
& $(4)$ & & & & \\
Johnson & $\& 0.2 \%(53)$ & $39.8 \%(35)$ & $.0 \%(0)$ & 64.028 & .000 \\
Johnson & & & & & \\
Oxy & $93.3 \%(14)$ & $6.7 \%(1)$ & $.0 \%(0)$ & 22.623 & .000 \\
Pond's & $5.3 \%(2)$ & $15.8 \%(6)$ & $78.9 \%(30)$ & 41.151 & .000 \\
Nivea & $7.1 \%(4)$ & $3.6 \%(2)$ & $89.3 \%(50)$ & 95.386 & .000 \\
Vaseline & $.0 \%(0)$ & $.0 \%(0)$ & $100.0 \%(65)$ & 162.760 & .000 \\
Caring & $.0 \%(0)$ & $100.0 \%(11)$ & $.0 \%(0)$ & 25.845 & .000 \\
The Body Shop & $.0 \%(0)$ & $100.0 \%(15)$ & $.0 \%(0)$ & 35.710 & .000 \\
Clean \& Clear & $.0 \%(0)$ & $100.0 \%(27)$ & $.0 \%(0)$ & 66.938 & .000 \\
Garnier & $8.6 \%(3)$ & $2.9 \%(1)$ & $88.6 \%(31)$ & 53.868 & .000 \\
Etude & $2.9 \%(1)$ & $5.9 \%(2)$ & $91.2 \%(31)$ & 59.556 & .000 \\
Citra (Unilever) & $.0 \%(0)$ & $4.3 \%(1)$ & $95.7 \%(22)$ & 43.209 & .000 \\
Skinfood & $5.0 \%(2)$ & $.0 \%(0)$ & $95.0 \%(38)$ & 78.091 & .000 \\
\hline
\end{tabular}

The Body Shop, L'Oreal and Oxy were also essential product makers in all countries. The number of product users is higher, especially in Malaysia even though L'Oreal and Oxy products do not contain the halal logo. This result indicates the likelihood that users prefer Oxy and L'Oreal because of the quality not because of their halal ingredients. Beauty users in Malaysia, Indonesia and Thailand preferred foreign brands to local brands despite the level of awareness of halal products and ingredients, including indigenous herbs that international brands do not offer. Therefore, indigenous branding strategies are less impactful on consumers' brand decisions that emphasize halal-ness and indigenous knowledge of herbs.

Table 8 shows that all respondents in Malaysia and Indonesia use one single product. Interestingly, Malaysian respondents did not use Indonesian cosmetic local products and Indonesians did not use Malaysian cosmetic products. This reveals that local cosmetic products do not have a market in the neighbouring countries even though the listed cosmetic products are certified halal products. Table 9 indicates that the beauty products of foreign brands 
were still part of the beauty and cosmetics sector in the two countries; Johnson \& Johnson enjoyed a high number of respondents in Malaysia (60.2\%) followed by Indonesia (39.8\%) because Johnson \& Johnson not only makes quality products, but also uses the halal logo to attract Muslim users in both countries. The Body Shop and Oxy were also important product brands for users. Although Oxy products and the Body Shop products do not contain a halal logo, the numbers of users of these brands are higher in Malaysia (Table 9). This result indicates the likelihood that users prefer Oxy because of its quality not because of its halal-ness or halal ingredients. These results contradict a respondent's view that the criterion of suitability and quality of a beauty product is dependent on whether or not the product is halal. In Oxy's case, responses reveal that even though it did not have halal certification, it is not crucial for some Muslim consumers in both countries but more so in Malaysia. It appears that halal and haram are not strictly followed by all Muslims. Tables 8 and 9 reveal that beauty product users in Indonesia and Malaysia prefer foreign brands to local brands despite the high level of awareness of halal products and ingredients that the foreign brands do not offer. The indigenous branding strategies stress the halal-ness and indigenous knowledge of herbs, but were less effective in motivating users to buy local brands. These findings refer to the quality and suitability factors in the selection of a beauty product, not the concept of halal-ness.

\section{Usefulness of halal beauty products}

Of the total 316 respondents, 148 (41\%) did not offer any response when asked if halal beauty products were useful to all; $59 \%$ provided different answers. Of the 59\%, 44 were Buddhists, 168 were Muslims and 1 was Christian. Amongst the 44 Buddhist respondents, six said that there were no benefits of halal products; 17 respondents were not sure if the halal products were useful and 21 respondents suggested that halal products were useful. Of the 168 Muslim respondents, 12 said that halal beauty products were not valuable, 20 said they were not sure and 136 claimed that halal products provided benefits for customers.

\section{Discussion}

The results of the survey reveal that religion plays a significant role in consumers' choices of beauty products, but it is not the only factor. Some other factors influence female consumers in their decisions to purchase cosmetic products (Briliana \& Mursito, 2017). An example is Oxy beauty products 
(Table 9) that do not have halal certification in Malaysia and Indonesia. However, the brand is bought by many Muslims. Additionally, the results in Table 3 show that the three countries' beauty product users prefer local products based on certain criteria. The criterion of halal-ness was not very strong in comparison to the criteria of quality, suitability and the ingredients used in beauty products. In their statements, some respondents offered responses that deviated from religious values. Through another longitudinal study, such views have to be compared with the respondents' routine practices of buying and using halal and non-halal cosmetic products. However, one respondent suggested that if halal standards were not met, consumers would not select the product even though the product suits them and its quality is good. We suggest that the majority of respondents selected a product based on halal certification.

This article also provides some evidence related to assertions that in the Southeast Asian markets, particularly in Muslim countries, the dominance of international companies has gradually weakened for obvious reasons that local companies have changed tactics (Nielsen Growth \& Emerging Markets, 2016; Schuiling \& Kapferer, 2004). The results of the current survey are rather contrastive: the local companies' tactics, such as the use of religious and cultural logos and knowledge, are less effective compared to the quality and suitability of beauty products that the majority of respondents $(>70 \%)$ had given top priority to and that halalness or halal certification could not get. Thus, it can be suggested that although international companies have ample presence and benefits in the local market space, this competitive space will always be there for international companies because of the possibility that the level of quality and standards followed by international companies producing cosmetic products, will always be higher. Therefore, it can be safely assumed that local companies would use all tactics and benefits of low operational costs, good networking and clear understanding of local peoples' tastes and needs (Nielsen Growth \& Emerging Markets, 2016). International companies have had to step ahead to attain greater consumer attraction by enhancing the quality and suitability of their cosmetic products. Local companies have to revisit their strategies of halal certification because international companies are still popular in Malaysia and Indonesia mainly due to suitability and quality factors, and as we have observed, most international brands such as Johnson \& Johnson, use halal certification in the Malaysian and Indonesian cosmetics markets.

The Nielsen Growth \& Emerging Markets (2016) Survey had entirely disregarded the role of religious concepts in the cosmetics market, concepts 
that many kinds of research (Majid et al., 2015; Shaari et al., 2014; Yunus et al., 2010; Johansson \& Ronkainen, 2005; Schuiling \& Kapferer, 2004) have endorsed. This article also demonstrates that in addition to quality and suitability, religious concept of halalness still maintained greater importance among consumers. The religious concept of halalness should not be taken for granted when surveying Indonesian and Malaysian cosmetics markets. Similarly, the legitimacy or credibility of indigenous knowledge (Yacob \& Zainol, 2013) still has to be tested vigorously in the same market because indigenous knowledge can be easily be challenged and overcome by international brands. Furthermore, the universal Islamic principle of halalness is not easy challenged. After the events of 9-11, we have seen a greater surge in adoption of an Islamic way of life. In other words, 9-11 has spread the message and principles of Islam more robustly than ever before (Abdo, 2006; Bilici, 2012). Therefore, in addition to halalness, local companies have to give due consideration to quality and suitability factors because international brands will use the same religious concepts to win the hearts and purchasing preferences of cosmetic consumers (The Express Tribune, 2016).

\section{Conclusion}

The findings of the current survey take us into two different directions: First, the findings show that the religious concept of halalness does have a total impact on consumer selection of cosmetic products. At the same time, a significant ratio of consumers bypassed religious barriers (concepts) to satisfy their tastes and needs by using beauty products that suited them and that are of high quality. Secondly, the findings also show that brands are only cultural and social as discussed in the literature by Thompson and Arsel (2004), Holt, Quelch and Taylor (2004), Cayla and Arnould (2008) when these products meet certain consumers' needs. However, when brands and products satisfy the needs of every type of consumer, whether Muslim or non-Muslim, Asian or non-Asian, then brands become needs-based brands that continue to survive and/or that benefit the company, as long as consumers continue to want brand products. In other words, brands and products remain part of the consumer culture for as long as consumers wish to use brand products.

Traditional and cultural practices of personal healthcare and lifestyle led to the creation of a niche market with an added advantage of indigenous knowledge- knowledge that foreign competition had limited access to such as post-natal care. Perhaps most importantly, indigenous knowledge empowers women and enhances their social position by providing a reliable source of income and social identity, and who are also crucial conservers of culture. The 
branding of beauty products by homegrown beauty companies in Islamic communities in Indonesia, Malaysia and Thailand, revolves significantly around religious concepts. International brands have a significant place in the three countries' markets even though brand products did not contain a halal logo, indicating that quality of the product was outstanding. Beauty product users in the three countries preferred foreign over local brands despite the high awareness level of halal products and ingredients including indigenous herbs that the international brands did not offer. The indigenous branding strategies that emphasized halalness and indigenous knowledge of herbs were less impactful on brand choice. Quality, suitability and ingredients took precedence over the halal factor. Thus, beauty companies should take advantage of these findings and enhance their products' attraction by securing halal certification while also focusing on the quality, suitability and indigenous ingredients of their beauty products.

\section{Acknowledgment}

The authors would like to acknowledge the International Institute of Public Policy and Management, University of Malaya, for the generous grant RG08209HNE. The authors also acknowledge the contributions made by respondents who patiently took part in this study. This study would not be possible without all of their assistance.

\section{References}

Abd-Jabar, F. A., Ishak, M., Johar, N., \& Wahid, S. N. S. (2014). A study on the relationship between awareness and knowledge of Muslim retailers toward Halal cosmetic products. In Proceedings of the International Conference on Science, Technology and Social Sciences (ICSTSS) 2012 (pp. 383-388). Singapore: Springer.

Abd-Rahman, A., Asrarhaghighi, E., \& Ab-Rahman, S. (2015). Consumers and Halal cosmetic products: Knowledge, religiosity, attitude and intention. Journal of Islamic Marketing, 6(1), 148-163.

Abdo, G. (2006). Mecca and Main Street: Muslim life in America after 9/11. New York: Oxford University Press.

Ahmad, A. N., Abd-Rahman, A., \&, Ab-Rahman, S. (2015). Assessing knowledge and religiosity on consumer behavior towards Halal food and cosmetic products. International Journal of Social Science and Humanity, 5(1), 10-14. 
Aisyah, M. (2015). Peer group effects on Moslem consumer's decision to purchase Halal labeled cosmetics. Al-Iqtishad: Journal of Islamic Economics, 7(2), 165-180.

Aisyah, M. (2017). Consumers demand on Halal cosmetics and personal care products in Indonesian. Journal of Islamic Economics, 9(1), 125 -142.

Alserhan, B. A. (2010). Islamic branding: A conceptualization of related terms. Brand Management, 18(1), 34-49.

Aziz, N. N. A., Wahab, E., Aziz, N. A. A., \& Aziz, N. A. A. (2014). Understanding the intention to purchase halal cosmetic products among consumers. Paper presented at the Third International Seminar on Entrepreneurship and Business (ISEB 2014), December 14, Kota Bharu, Malaysia. Retrieved from http://umkeprints.umk.edu.my/4932/

Aziz, Y. A., \& Chok, N. V. (2013). The role of Halal awareness, Halal certification, and marketing components in determining Halal purchase intention among non-Muslims in Malaysia: A structural equation modeling approach. Journal of International Food $\mathcal{E}$ Agribusiness Marketing, 25(1), 1-23.

Azmawani Abd. Rahman, Ebrahim Asrarhaghighi, \& Suhaimi Ab. Rahman. (2015). Consumers and Halal cosmetic products: Knowledge, religiosity, attitude and intention. Journal of Islamic Marketing, 6(1), 148163. Retrieved from https://doi.org/10.1108/JIMA-09-2013-0068

Bilici, M. (2012). Finding Mecca in America: How Islam is becoming an American religion. Chicago: University of Chicago Press.

Briliana, V., \& Mursito, N. (2017). Exploring antecedents and consequences of Indonesian Muslim youths' attitude towards halal cosmetic products: A case study in Jakarta. Asia Pacific Management Review, 22(4), 176-184.

Butt, M. M., Rose, S., Wilkins, S., \& Ul Haq, J. (2017). MNCs and religious influences in global markets: Drivers of consumer-based halal brand equity. International Marketing Review, 34(6), 885-908.

Cayla, J., \& Arnould, E. J. (2008). A cultural approach to branding in the global marketplace. Journal of International Marketing, 16(4), 86-112.

Cayla, J., \& Eckhardt, G. M. (2007). Asian brands without borders: Regional opportunities and challenges. International Marketing Review, 24(4), 444456.

Chan, L. (2017). 13 Malaysian beauty brands owned by women. Retrieved from http://www.elle.my/beauty/Features/gallery/13-Malaysianbeauty-brands-owned-by-women

Church, R. (1993). The family firm in industrial capitalism: International perspectives on hypotheses and history. Business History, 35(4), 17-27. 
CIA. (2018). Malaysia: The world factbook. Retrieved from https://www.cia.gov/library/publications/the-worldfactbook/geos/my.html

Czinkota, M. R., \& Ronkainen, I. A. (2003). An international marketing manifesto. Journal of International Marketing, 11(1), 13-27.

Emirates Business 24/7. (2009, June 29). Crackdown on cosmetics using banned substances. Emirates Business 24/7. Retrieved from https://www.emirates247.com/eb247/companiesmarkets/retail/crackdown-on-cosmetics-using-banned-substances2009-06-29-1.26608

Hai, M. M. A. (2001). Holy life of Pophet Muhammad (Hayat-E-Tayyaba). New Delhi: Maktaba-Al-Hasanat.

Hashim, P., \& Mat Hashim, D. (2013). A review of cosmetic and personal care products: Halal perspective and detection of ingredient. Pertanika Journals of Science and Technology, 21, 281-292.

Hassali A., Al-Tamimi S. K., Dawood, O. T., Verma, A. K., Saleem, F. (2015). Malaysian cosmetic market: Current and future prospects. Pharmaceutical Regulatory Affairs: Open Access, 4(4), 1-3. doi: 10.4172/2167-7689.1000155

Hogan, S., Almquist, E., \& Glynn, S. E. (2005). Brand-building: finding the touchpoints that count. Journal of Business Strategy, 26(2), 11-18.

Holt, D. B., Quelch, J. A., \& Taylor, E. L. (2004). How global brands compete. Harvard Business Review, 82(9), 68-75.

Horizon. (2018). Paving the way for Halal cosmetic. Retrieved from http://www.thailandhorizon.com/2017/index.php/km-kh/industry/363-

Husain R., Ghani, I. A., Mohammad, A., \& Mehad, S. (2012). Current practices among Halal cosmetics manufacturers in Malaysia. Journal of Statistical Modeling and Analytic, 39(1), 46-51.

Johansson, J. K., \& Ronkainen, I. A. (2005). The esteem of global brands. Journal of Brand Management, 12(5), 339-354.

Kaur, K., \& Osman, S. (2014). Predicting working women purchasing behaviour of Malaysian Halal cosmetic products by using theory of planned behaviour. International Academic Research Journal od Business and Management, 3(1), 1-7.

Kawa, L. W., Rahmadiani, S. F., \& Kumar, S. (2013). Factors affecting consumer decision-making: a survey of young-adults on imported cosmetics in Jabodetabek, Indonesia. SIJ Transactions on Industrial, Financial $\mathcal{E}$ Business Management, 1(5), 175-180. 
Kim, J., Han, W., Kim, D., \& Paramita, W. (2013). Is beauty in the eye of the beholder? Gender and beauty in the cosmetics sector: A comparative study of Indonesia and Korea. Marketing Intelligence \& Planning, 31(2), 127-140.

Kordnaeij, A., Askaripoor, H., \& Bakhshizadeh, A. (2013). Studying affecting factors on customers' attitude toward products with halal brand (case study: Kuala Lumpur, Malaysia). International Research Journal of Applied and Basic Sciences, 4(10), 3138-3145.

Majid, M. B., Sabir, I., \& Ashraf, T. (2015). Consumer purchase intention towards Halal cosmetics \& personal care products in Pakistan. Global Journal of Research in Business \& Management, 1(1), 47 - 55.

Melewar, T., \& Walker, C. (2003). Global corporate brand building: Guidelines and case studies. Journal of Brand Management, 11( 2), 157-170.

Nielsen Growth \& Emerging Markets. (2016). Go glocal: To win the hearts and carts of Southeast Asian consumers. Retrieved from http://www.nielsen.com/content/dam/nielsenglobal/apac/docs/reports/ 2016/nielsen-go-glocal-report.pdf

Özsomer, A. (2012) The interplay between global and local brands: A closer look at perceived brand globalness and local iconness. Journal of International Marketing, 20(2), 72-95.

Purbasari. (2018). Ini caranya memilih kosmetik yang aman. Retrieved from http://purbasari.com/

Reisman, D. (2004). Schumpeter's market: Enteprise and evolution. Cheltenham, UK: Edward Elgar.

Sayyed, R. (2017). Asian cosmetic giant designs make-up products for Muslim women in Southeast Asia. Retrieved from http://mvslim.com/asiancosmetic-giant-designs-make-up-products-for-muslim-women-insoutheast-asia/

Schuiling, I., \& Kapferer, J. N. (2004). Executive insights: Real differences between local and international brands: strategic implications for international marketers. Journal of International Marketing, 12(4), 97-112.

Schumpeter, J. A. (1934). Theory of economic development. Cambridge: Harvard University Press.

Sendayu Tinggi. (2018). Sendayu Tinggi. Retrieved from https://www.facebook.com/HQ.SendayuTinggi/

Shaari, J. A. N., Khalique, M., \& Aleefah, F. (2014). Halal restaurant: What makes Muslim in Kuching confident? Journal of Economic Development, Management, IT, Finance and Marketing, 6(1), 23 - 34. 
Simon, F., \& Kotler, P. (2003). Building global biobrands: Taking biotechnology to market. New York: Simon \& Schuster.

State of the Global Islamic Economic Report 2017/18. (2017, November 27). Retrieved

https://www.salaamgateway.com/en/story/ReportStateoftheGlobalIsla micEconomy201718-SALAAM27112017104745/

Statista. (n.d.). Market value of halal cosmetics worldwide. Retrieved from https://www.statista.com/statistics/794762/market-value-of-halalcosmetics-worldwide/

Sulaiman, M. A. B. A., Hisam, M. W., \& Sanyal, S. (2013). Ethical business practices in Islam. Purushartha: A Journal of Management Ethics and Spirituality, 6(2).

Sutono. (2015). Understanding of the Halalan Tayyiban concept towards purchase intention of halal cosmetics among young urban Muslim consumers. In UPM-SAGE Publications young Writer's Award 2015 Papers (pp. 214-235). Serdang: Perpustakaan Sultan Abdul Samad, Universiti Putra Malaysia.

Teng, P. K., \& Jamaliah, W. W. (2013). Investigating students awareness and usage intention towards halal labelled cosmetics and personal care products in Malaysia. In Proceedings of the 4th International Conference on Business and Economic Research (4th ICBER 2013), 4-5 th March 2013, Bandung, Indonesia (pp. 137-155). Bangi: Conference Master Resources.

The Express Tribune. (2016). Consumer giants court Muslims halal face creams, shampoos. Retrieved from https://tribune.com.pk/story/1174737/consumer-giants-court-muslimshalal-face-creams-shampoos/

Thompson, C. J., \& Arsel, Z. (2004). The Starbucks brandscape and consumers' (anticorporate) experiences of glocalization. Journal of Consumer Research, 31(3), 631-642.

UNESCO. (n.d.). What is local and indigenous knowledge? Retrieved from http://www.unesco.org/new/en/natural-sciences/priorityareas/links/related-information/what-is-local-and-indigenousknowledge/

Wadood, A. (2008). What is tayyib? Retrieved from https://tayyibaat.wordpress.com/2008/09/04/what-is-tayyib/

Wane, N. N. (2013). [Re]claiming indigenous knowledge: challenges, resistance, and opportunities. Decolonization: Indigeneity, Education $\mathcal{E}$ Society, 2(1), 39-107. 
Wardah Cosmetic. (2018). Wardah. Retrieved from http://www.wardahbeauty.com/

Xiang Meng. (2014) Customer intention to purchase halal cosmetics in Malaysia. Doctoral dissertation, College of Law, Government, and International Studies, Universiti Utara Malaysia, Sintok, Malaysia. Retrieved from http://etd.uum.edu.my/4220/2/s811882_abstract.pdf

Yacob, S., \& Zainol, R. (2013). Going global: Branding strategies in the Malaysian beauty industry. SARJANA: Journal of the Faculty of Arts $\mathcal{E}$ Social Sciences, University of Malaya, 28(2), 65-78.

Yunus, A. B. M., Wan Chik, W. M. Y. B., \& Mohamad, M. B. (2010) The concept of halalan tayyiba and its application in products marketing: A case study at Sabasun HyperRuncit Kuala Terengganu, Malaysia. International Journal of Business and Social Science, 1(3): 239-248.

Date Received: 15 November 2017 Date of acceptance: 15 April 2018 